\title{
Detection and Quantification of Pratylenchus thornei in DNA Extracted from Soil Using Real-Time PCR
}

\author{
Guiping Yan, Richard W. Smiley, and Patricia A. Okubara
}

First and second authors: Oregon State University, Columbia Basin Agricultural Research Center, P.O. Box 370, Pendleton 97801; and third author: United States Department of Agriculture-Agricultural Research Service, Root Disease and Biological Control Research Unit, Pullman, WA 99164-6430.

Accepted for publication 23 August 2011.

\begin{abstract}
Yan, G. P., Smiley, R. W., and Okubara, P. A. 2012. Detection and quantification of Pratylenchus thornei in DNA extracted from soil using realtime PCR. Phytopathology 102:14-22.

The root-lesion nematode Pratylenchus thornei is one of the most important pests restricting productivity of wheat in the Pacific Northwest (PNW). It is laborious and difficult to use microscopy to count and identify the nematodes in soils. A SYBR Green I-based real-time polymerase chain reaction (PCR) assay was developed to detect and quantify this species from DNA extracts of soil. A primer set, designed

PNW wheat fields. A standard curve relating threshold cycle and log values of nematode number was generated from artificially infested soils. The standard curve was supported by a high correlation between the numbers of $P$. thornei added to soil and the numbers quantified using realtime PCR. Examination of 15 PNW dryland field soils and 20 greenhouse samples revealed significant positive correlations between the numbers determined by real-time PCR and by the Whitehead tray and microscopic method. Real-time PCR is a rapid, sensitive alternative to time-consuming nematode extractions, microscopic identification, and counting of P. thornei from field and greenhouse soils.
\end{abstract} from the internal transcribed spacer region (ITS1) of rDNA, was highly specific to $P$. thornei and did not amplify DNA from 27 isolates of other Pratylenchus spp., other nematodes, and six fungal species present in
Additional keywords: in silico analysis, root disease.
Pratylenchus thornei is one of the most important root-lesion nematodes that restrict productivity of wheat in the Pacific Northwest (PNW) (29,31). It is estimated that $P$. thornei combined with another damaging root-lesion nematode species, $P$. neglectus, reduces profitability of farms in Idaho, Oregon, and Washington by $\approx \$ 51$ million annually (26). $P$. thornei and $P$. neglectus have the potential for causing economic damage on as many as $60 \%$ of dryland wheat fields in the PNW $(29,33)$. High populations occur individually or as mixtures of species (29). These species are well adapted to dry environments $(7,30)$ and can reduce yields of intolerant wheat cultivars as much as $60 \%$ without causing obvious foliar and root symptoms $(28,31,32)$. Wheat yield is often inversely correlated with pre-plant population $(30,31)$. Lesion nematodes are very important in drier areas because they reduce the extraction of stored water by host plants from soil profiles $(28,30,35)$. Plants in wetter environments are more capable of compensating for damage from a given pre-plant population.

Management practices for lesion nematodes on cereal crops are limited in regions of low precipitation (30). Nematicides are either not registered or are ineffective on wheat, and tillage has little effect (28). Crop rotation in dryland cropping systems generally does not reduce lesion nematode population density (28). Canola, chickpea, winter pea, lentil, and mustard appear to allow sufficient reproduction of one or both Pratylenchus spp. and thereby increase risk to subsequent intolerant wheat crops $(28-30,35,37)$. Biofumigant crops, for which green tissue must be incorporated into soil before activating and releasing compounds toxic to nematodes, are not used in rainfed PNW crops because they deplete water that is needed for wheat plants.

Corresponding author: G. P. Yan; E-mail address: guiping.yan@ oregonstate.edu

http://dx.doi.org/10.1094/PHYTO-03-11-0093

(c) 2012 The American Phytopathological Society
The best approach to control damage from lesion nematodes that are present at high population densities in soil at the time of planting is to select and grow cultivars that are both resistant and tolerant $(30,35,37)$. Variable climate, host tolerance, and nematode virulence make it difficult to assign economic damage thresholds for these species (7). However, it was clear that initial Pratylenchus populations as low as 2,000 nematodes $/ \mathrm{kg}$ of soil were able to limit grain yield in the PNW $(31,32)$. Moreover, individual wheat cultivars differ in their reaction to each nematode species; cultivars with resistance or tolerance to one species are not necessarily resistant or tolerant to another species (26). Thus, selection of optimal cultivars requires that the species of lesion nematodes present in each field or region be accurately identified and quantified.

It is a challenge to distinguish $P$. thornei from $P$. neglectus and also from other closely related Pratylenchus spp. on the basis of morphological characteristics $(9,12)$. It is particularly laborious and difficult to use microscopy to count and identify these species in large numbers of field soil samples in which many other plantparasitic and non-plant-parasitic nematode species are also present. Therefore, a quick, sensitive, and reliable molecular diagnostic method is needed to detect and quantify these lesion nematode species.

Polymerase chain reaction (PCR) restriction fragment length polymorphism has been used to distinguish Pratylenchus spp., including $P$. thornei and $P$. neglectus $(34,38)$. PCR amplification using species-specific primers followed by gel electrophoresis has been utilized effectively for distinguishing species of Pratylenchus $(1,5,41)$. Al-Banna et al. (1) discriminated $P$. thornei and $P$. neglectus as well as four other Pratylenchus spp. using PCR and species-specific primers designed from the D3 expansion domain of the 28S rRNA. Carrasco-Ballesteros et al. (5) identified $P$. thornei from different life stages of this nematode using PCR and sequence-characterized amplified region (SCAR) primers designed 
from a unique randomly amplified polymorphic DNA fragment. Yan et al. (41) developed species-specific PCR to detect and distinguish $P$. thornei and P. neglectus from DNA extracts of soil. This method is capable of clearly separating these two nematode species but it, as well as the abovementioned methods, are not quantitative. Quantitative real-time PCR provides opportunities for simultaneous identification of microorganisms based on target DNA specificity, and quantification of target DNA based on the number of cycles of amplification needed to first detect the DNA $(2,4,17)$. Real-time PCR has been used for detection and quantification of $P$. vulnus, $P$. zeae, and $P$. penetrans $(3,21,24)$. However, there are no published reports describing real-time PCR for P. thornei or P. neglectus. A commercial lab in Australia provides that service $(13,19,22)$ but the protocols are proprietary (19). Open-source real-time PCR is needed to improve the detection and quantification of these Pratylenchus spp. for research and commercial diagnostic laboratories. At least one PNW commercial lab currently uses real-time PCR to detect and quantify several other crop pests but is lacking a protocol for the principal nematode pests of wheat.

The objectives of this study were to develop a real-time PCR assay to facilitate the detection, identification, and quantification of $P$. thornei from soil, and to determine whether the assay was applicable to a wide range of soils inhabited by this nematode and over a range of population densities.

\section{MATERIALS AND METHODS}

DNA extraction from pure cultures and soils. Nematodes were manually isolated from soil samples using the Whitehead tray method (39). A single adult female was morphologically identified $(9,12)$ as $P$. thornei and then placed onto sterilized carrot disks to establish pure cultures. Carrot cultures were incubated at $22^{\circ} \mathrm{C}$ for at least 3 months. Nematodes were extracted from carrot by cutting the disks into thin slices and floating the carrot pieces in distilled water in a petri dish. Pure nematodes were recovered using a sieve $(20 \mu \mathrm{m})$. Nematode DNA was extracted from the pure cultures following the protocol of Yan et al. (41) using a lysis buffer prepared in the laboratory $(500 \mathrm{mM}$ $\mathrm{KCl}, 100 \mathrm{mM}$ Tris-Cl [pH 8.3], $15 \mathrm{mM} \mathrm{MgCl}_{2}, 10 \mathrm{mM}$ dithiothreitol, $4.5 \%$ Tween 20 , and $0.1 \%$ gelatin).

To analyze nematode DNA in artificially infested soil, natural field soil, and greenhouse soil, total DNA was extracted from soil using the PowerSoil DNA Isolation Kit (MoBio, Carlsbad, CA) and the MO BIO Vortex Adapter tube holder at a maximum speed of 8 for $10 \mathrm{~min}$ according to the manufacturer's recommendations, except that $0.5 \mathrm{~g}$ of soil instead of $0.25 \mathrm{~g}$ was used in this study. DNA was quantified using the NanoDrop ND-1000 Spectrophotometer (Wilmington, DE).

Primer selection. The $P$. thornei-specific forward primer THOITS-F2 (5'-GTGTGTCGCTGAGCAGTTGTTGCC-3') and the reverse primer THO-ITS-R2 (5'-GTTGCTGGCGTCCCCAGTC AATG-3') were designed from the internal transcribed spacer (ITS) region (ITS1) of the nuclear ribosomal RNA genes. Pratylenchus ribosomal DNA sequences were obtained from GenBank (FJ712956, FJ712952, FJ717818, FJ717819, FJ713005, FJ713004, FJ713003, FJ713002, FJ717820, FJ717821, FJ712987, FJ712991, FJ712978, and FJ712959). This primer pair produced a deduced amplicon that was $131 \mathrm{bp}$ in length. These primers, along with 10 other potential primers, were analyzed for annealing temperature, GC content, and self hybridization using the computer software GeneRunner (version 3.05; Hastings Software, Inc., Hudson, NY) and primer dimer duplex formation using OLIGO 4.0 (23). Primers were synthesized using cartridge purification to remove short synthesis products (Invitrogen, Carlsbad, CA). Performance of each primer pair was evaluated on the basis of amplification of only the target DNA, great endpoint fluorescence, and high amplification efficiency. Amplification efficiency (E) was calculated from the slope of a plot of log nematode DNA ( $\mathrm{x}$-axis) versus cycle threshold $(\mathrm{Ct})\left(\mathrm{y}\right.$-axis), where $\mathrm{E}=10^{(1 /-\mathrm{m})}-1$ and $\mathrm{m}$ is slope of the plot (10).

Primer specificity. DNA of four $P$. thornei and six P. neglectus isolates from Oregon, Washington, Montana, and Idaho, maintained in carrot cultures, was used to examine the specificity of PCR primers (Table 1). DNA samples from the isolates of five other Pratylenchus spp., three Meloidogyne spp., five plant-parasitic nematode species in other genera, and six fungal species commonly associated with wheat root diseases were also used as non-target controls (Table 1). Three replicated PCR reactions were performed for each isolate.

To expand the specificity evaluation to DNA from additional nematode isolates and species that could not be obtained upon request, an in silico analysis was conducted using GenBank ITS sequences from 21 Pratylenchus spp. (Table 2) and the computer software PrimerSelect 5.00 (DNASTAR, Inc., Madison, WI). Specificity of THO-ITS-F2 and THO-ITS-R2 to the sequences of non-target Pratylenchus spp. was evaluated from primer-template duplex stability values $(\Delta \mathrm{G})$ as described by Schroeder et al. (25) and Okubara et al. (18).

Real-time PCR assay. Amplification reactions were performed using the capillary-based LightCycler thermocycler (Roche Applied Science, Indianapolis, IN) and FastStart DNA Master SYBR green I dye (Roche Applied Science). Real-time PCR was conducted following the protocols described by Schroeder et al. (25) and Okubara et al. (18), with some modifications. PCR reactions of $10 \mu \mathrm{l}$ contained $1 \mu \mathrm{l}$ of template DNA, $1 \mu \mathrm{l}$ of Master SYBR green I mix, $3 \mathrm{mM} \mathrm{MgCl} 2,5$ pmol of each primer, and $5.8 \mu \mathrm{l}$ of nanopure water. The amplification program consisted of initial denaturation of $10 \mathrm{~min}$ at $95^{\circ} \mathrm{C}$ followed by up to 50 cycles of $95^{\circ} \mathrm{C}$ for $5 \mathrm{~s}, 70^{\circ} \mathrm{C}$ for $10 \mathrm{~s}$, and $72^{\circ} \mathrm{C}$ for $10 \mathrm{~s}$, with fluorescence monitored after each annealing step. Melting curve profiles were used to detect potential primer dimers and nonspecific amplification products. Amplicon melting profiles were obtained by increasing the temperature of the reaction from 70 to $95^{\circ} \mathrm{C}$ in increments of $0.1^{\circ} \mathrm{C}$ per 0.4 to 0.5 fluorescence units. DNA from pure cultures of $P$. thorne $i$ was used as the positive control and sterilized nanopure water was used as the negative control. All samples in this study were amplified in duplicate or triplicate. The resulting data were analyzed with a program (LightCycler software, version 3.5) using the arithmetic baseline adjustment and second derivative maximum analysis to generate amplification curves, standard curves, and melting curves.

Standard curves from pure culture and soil. Standard curves were generated using nematode DNA from the Pt1 isolate (Table 1) raised in carrot cultures. One thousand nematodes of mixed stages, including eggs, juveniles, and adult females, were put onto $30 \mu \mathrm{l}$ of sterilized nanopure water in an Eppendorf tube and homogenized with a round pipette tip for $10 \mathrm{~min}$. Lysis buffer $(24 \mu \mathrm{l})$ (described in DNA extraction from pure cultures and soils) and $6 \mu \mathrm{l}$ of proteinase $\mathrm{K}$ at $600 \mu \mathrm{g} / \mathrm{ml}$ were added to the tube. DNA from these nematodes was extracted and quantified following the method described by Yan et al. (41). Nematode DNA was serially diluted with sterilized nanopure water to give $82 \mathrm{ng} / \mu \mathrm{l}$ to $82 \mathrm{pg} / \mu \mathrm{l}$ (Table 3 ). The series of DNA dilutions were used in realtime PCR reactions. Standard curves were generated by plotting logarithmic values of DNA concentration versus $\mathrm{Ct}$ values.

To relate $\mathrm{Ct}$ value to number of $P$. thornei per gram of soil, a separate standard curve was generated from artificially infested soil. Juveniles, adult females, and eggs of $P$. thornei $(0.5,1,5,20$, $100,500$, and 1,000$)$ were added separately to $0.5 \mathrm{~g}$ of sterilized soil. The soil (Walla Walla silt loam) was collected from Pendleton, OR and harbored no detectable $P$. thornei or P. neglectus. The soil was sieved through a $3-\mathrm{mm}$ sieve and autoclaved $\left(121^{\circ} \mathrm{C}, 115\right.$ $\mathrm{kPa}$ ) two times for $45 \mathrm{~min}$ each time to kill living organisms. Total DNA was extracted from infested soils using the PowerSoil DNA Isolation Kit (MoBio). The standard curve was generated by 
plotting logarithmic values of the number of nematodes per gram of soil versus the corresponding $\mathrm{Ct}$ values.

To validate the soil standard curve, pure $P$. thornei $(1,5,20$, 100 , and 500 nematodes) was added separately to $0.5 \mathrm{~g}$ of sterilized soil in four replicates. Mixtures of $P$. thornei $(\mathrm{Pt})$ and $P$. neglectus $(\mathrm{Pn})$ were also inoculated into a different set of $0.5-\mathrm{g}$ batches of soil at the following ratios in duplicate: $0.5 \mathrm{Pt}+9.5 \mathrm{Pn}$, $1 \mathrm{Pt}+9 \mathrm{Pn}, \quad 2 \mathrm{Pt}+8 \mathrm{Pn}, \quad 3 \mathrm{Pt}+7 \mathrm{Pn}, \quad 4 \mathrm{Pt}+6 \mathrm{Pn}, \quad 5 \mathrm{Pt}+5 \mathrm{Pn}, \quad 6 \mathrm{Pt}+4 \mathrm{Pn}$, $7 \mathrm{Pt}+3 \mathrm{Pn}, 8 \mathrm{Pt}+2 \mathrm{Pn}, 9 \mathrm{Pt}+1 \mathrm{Pn}$, and $9.5 \mathrm{Pt}+0.5 \mathrm{Pn}$, for a total of 10 nematodes in each mixture. DNA (42 samples) was used in the standard curve validation assay.

To examine the potential presence of PCR inhibitors in the soil that was used for generation of the standard curve, nematode DNA from a pure culture of Pt1 was serially diluted with extracts of the sterilized and noninfested Walla Walla silt loam soil as well as with water (Table 3). Amplification efficiencies (E) were calculated using the abovementioned formula. Inhibitor activity could be detected by comparing E from DNA in soil extracts to E from DNA in water.

Field soil samples. Fifteen soil samples were collected from dryland wheat fields in Oregon and Washington during 2008 (Table 4). Each soil was mixed well, divided, and submitted to four commercial and research labs in the PNW for nematode identification and quantification using microscopic procedures. Lab 1 utilized the Whitehead tray method for nematode extraction (39) and labs 2 to 4 used the wet-sieving and sugar-density flotation methods (14). Nematodes were isolated from 100 to $500 \mathrm{~g}$ of soil and expressed as the number per kilogram of soil. Species identification of $P$. thornei and $P$. neglectus was available upon special request with additional diagnostic fee. The two species were distinguished based on the morphological difference in tail shape and vulva position $(9,12,41)$. Adult females were morpho- logically identified as $P$. thornei with a slightly truncated tail on end and vulva position at 73 to $80 \%$ or P. neglectus with a pointed but still round tail and vulva position at 76 to $87 \%$. Species identity in each soil sample was also confirmed by a conventional PCR method as described by Yan et al. (41). Nematode DNA was extracted from $0.5 \mathrm{~g}$ of soil and analyzed using real-time PCR and the soil standard curve. Three independent DNA extractions were conducted for each soil sample and each extract was assayed in duplicate real-time PCR reactions.

Greenhouse samples. Twenty samples from a wheat germplasm resistance trial were used to test the real-time PCR assay. In this trial, $F_{3}$ lines and parental lines of the cross 'Persia 20' $\times$ 'Alpowa' were evaluated for resistance under controlled greenhouse conditions in 2010. Plants were grown in plastic tubes, each containing $150 \mathrm{~g}$ of partially sterilized Walla Walla silt-loam soil. Each pot with a single plant at the one-leaf stage was inoculated with $300 P$. thornei derived from pure cultures maintained on wheat roots. The species identity was confirmed morphologically and molecularly using the methods described by Yan et al. (41). After 16 weeks of incubation, plant tops were removed, roots were cut to fine pieces and mixed thoroughly with soil, and nematodes were extracted from the soil and plant roots using the Whitehead tray method $(26,30)$. Nematodes in $1 \mathrm{ml}$ of extracted suspension were quantified on a nematode-counting slide under a microscope, and converted to the number per kilogram of soil plus roots. Nematode DNA was extracted from $0.5 \mathrm{~g}$ of soil of each subsample and quantified using real-time PCR and the soil standard curve. Multiplication rate, which is an index of resistance, was calculated by dividing the final population of nematodes by the initial population in each pot (30). The $\mathrm{F}_{3}$ lines were classified as resistant (R), intermediate (I), and susceptible (S) based on the multiplication rate.

TABLE 1. Pratylenchus spp. and other nematode and fungal species used to evaluate the Pratylenchus thornei real-time polymerase chain reaction primers

\begin{tabular}{|c|c|c|c|c|}
\hline Species & Isolate & Origin & Host & Source ${ }^{a}$ \\
\hline \multicolumn{5}{|l|}{ Nematodes } \\
\hline P. thornei & Pt1 & Pendleton, OR & Wheat & R. Smiley \\
\hline P. thornei & $\mathrm{Pt} 2$ & Pendleton, OR & Wheat & R. Smiley \\
\hline P. thornei & Pt3 & Pendleton, OR & Wheat & R. Smiley \\
\hline P. thornei & $\mathrm{Pt} 4$ & Mission, OR & Wheat & R. Smiley \\
\hline P. neglectus & Pn1 & La Grande, OR & Wheat & R. Smiley \\
\hline P. neglectus & Pn2 & Lind, WA & Wheat & R. Smiley \\
\hline P. neglectus & Pn3 & Moro, OR & Wheat & R. Smiley \\
\hline P. neglectus & Pn4 & Heppner, OR & Wheat & R. Smiley \\
\hline P. neglectus & Pn5 & Great Falls, MT & Wheat & A. Dyer \\
\hline P. neglectus & Pn6 & Canyon County, ID & Potato & S. Hafez \\
\hline$P$. agilis & 031302 & Wye, MD & Corn & A. Skantar \\
\hline P. crenatus & 012204 & Clarksville, MD & Grass & A. Skantar \\
\hline P. zeae & 030204 & $\mathrm{NC}$ & Corn & A. Skantar \\
\hline P. scribneri & 062805 & Homestead, FL & Tomato & A. Skantar \\
\hline P. scribneri & 032102 & Seneca County, OH & Corn & A. Skantar \\
\hline P. penetrans & 030402 & NY & Corn & A. Skantar \\
\hline P. penetrans & 052704 & WI & Potato & A. Skantar \\
\hline Meloidogyne naasi & 110704 & Linn County, OR & Oat, wheat & A. Skantar \\
\hline M. chitwoodi & 110504 & Parma, ID & Potato & A. Skantar \\
\hline M. hapla & 070808 & Prosser, WA & Grape & E. Riga \\
\hline Heterodera avenae & $\mathrm{Ha}$ & La Grande, OR & Wheat & R. Smiley \\
\hline H. filipjevi & Hf & La Grande, OR & Wheat & R. Smiley \\
\hline Tylenchorhynchus sp. & Ty & Pendleton, OR & Wheat & S. Easley \\
\hline Merlinius brevidens & $\mathrm{Mb}$ & Pendleton, OR & Wheat & G. Yan \\
\hline Paratylenchus sp. & $\mathrm{Pa}$ & La Grande, OR & Wheat & G. Yan \\
\hline \multicolumn{5}{|l|}{ Fungi } \\
\hline Bipolaris sorokiniana & $103-18$ & Walla Walla, WA & Wheat & R. Smiley \\
\hline Fusarium culmorum & R5321 & Chatham, Ontario, Canada & Wheat & R. Smiley \\
\hline F. pseudograminearum & $032-06$ & Moro, OR & Wheat & R. Smiley \\
\hline Gaeumannomyces graminis var. tritici & 99401 & Dayton, WA & Wheat & R. Smiley \\
\hline Rhizoctonia oryzae & $2-3-2$ & Wenatchee, WA & Wheat & M. Mazzola \\
\hline R. solani $\mathrm{AG}-8$ & 1727B & Wenatchee, WA & Wheat & M. Mazzola \\
\hline
\end{tabular}

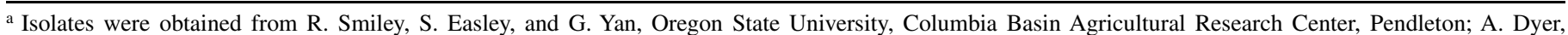
Montana State University, Bozeman; S. Hafez, University of Idaho, Southwest Idaho Research and Extension Center, Parma; A. Skantar, United States Department of Agriculture-Agricultural Research Service (USDA-ARS), Nematology Laboratory, Beltsville, MD; E. Riga, Washington State University, Irrigated Agriculture Research and Extension Center, Prosser; and M. Mazzola, USDA-ARS, Wenatchee, WA. 
Statistical analysis. Relationship between nematode numbers based on the real-time PCR assay and traditional microscopic method was determined using PROC REG in SAS (version 9.1, Statistical Analysis System; SAS Institute, Cary, NC). Where a significant correlation occurred $\left(R^{2}>0.5, P<0.05\right)$, comparison between the two estimates from the real-time PCR assay and microscopic method was conducted by paired $t$ test (PROC TTEST) and analysis of variance (PROC ANOVA) in SAS 9.1. An acceptance of the null hypothesis $(P>0.05)$ indicates that there is no significant difference between nematode counts obtained from the two procedures.

\section{RESULTS}

Primer specificity. The primer pair THO-ITS-F2/THO-ITS-R2 amplified $P$. thornei and produced only a single peak at $88.4^{\circ} \mathrm{C}$ (Fig. 1) in melting curve analysis. Nonspecific products were not produced using this primer pair. The $P$. thornei primer pair did not amplify DNA from $P$. neglectus isolates Pn1, Pn2, Pn3, Pn4, Pn5, and Pn6 (Table 1). Furthermore, this primer pair did not amplify DNA from seven isolates of five other non-target Pratylenchus spp. Likewise, they did not amplify DNA from eight other plant-parasitic nematode species and six fungal species found in PNW soils (Table 1). Ct values observed from these templates were high $(\mathrm{Ct}>40)$ and not different than those from water controls.

In silico analysis (Table 2) for the $P$. thornei primer pair indicated strong specific annealing with the ITS sequences of seven other $P$. thornei isolates from Spain and California based on duplex stability $(\Delta G)$ values. Specific annealing was reflected in $\Delta \mathrm{G}$ values that were $\leq-39 \mathrm{kcal} / \mathrm{mol}$. Only the forward primer formed a hybrid with the ITS sequences of $P$. goodeyi and $P$. vul$n u s$, at $\Delta \mathrm{G}$ values of -27.9 and -20.3 , respectively. These rela- tively high $\Delta \mathrm{G}$ values are predictive of poor primer-target binding, and PCR is not expected to generate logarithmic amplification (18). The reverse primer hybridized to the ITS sequence of $P$. mediterraneus at $\Delta \mathrm{G}=-47.4$. Although this duplex is predicted to be stable, amplification from a single primer fails to generate enough products to be detected in the real-time PCR system (18). Therefore, the $P$. thornei primer pair was not predicted to form productive duplexes with any of the ITS sequences from the 20 non-target Pratylenchus spp. (a total of 24 isolates).

DNA extraction from soil. Nematode DNA was extracted directly from soil using the PowerSoil DNA Isolation Kit (MoBio). To examine the presence of inhibitors that might interfere with fluorescence generated in the real-time PCR reaction, amplification of $P$. thornei DNA serially diluted with water was compared with that of DNA diluted with extracts of sterilized and non-

TABLE 3. Cycle threshold $(\mathrm{Ct})$ values from a seven-point serial dilution of Pratylenchus thornei DNA in water or soil extract ${ }^{\mathrm{a}}$

\begin{tabular}{lccc}
\hline & & \multicolumn{2}{c}{ Ct values } \\
\cline { 3 - 4 } Serial dilutions & DNA $^{\mathrm{b}}$ & Water & Soil extract \\
\hline $1: 1$ & $82.3 \mathrm{ng}$ & 19.3 & 19.7 \\
$1: 5$ & $16.5 \mathrm{ng}$ & 21.7 & 21.4 \\
$1: 10$ & $8.3 \mathrm{ng}$ & 22.3 & 21.7 \\
$1: 50$ & $1.7 \mathrm{ng}$ & 24.9 & 25.1 \\
$1: 100$ & $825 \mathrm{pg}$ & 25.5 & 25.4 \\
$1: 500$ & $165 \mathrm{pg}$ & 28.4 & 28.6 \\
$1: 1,000$ & $82.5 \mathrm{pg}$ & 29.6 & 29.7 \\
Efficiency $^{\mathrm{c}}$ & $\ldots$ & 0.96 & 0.95 \\
\hline
\end{tabular}

a Soil extract $=$ extracts of Walla Walla silt loam harboring no detectable $P$. thornei or P. neglectus; soil was autoclaved $\left(121^{\circ} \mathrm{C}, 115 \mathrm{kPa}\right)$ two times.

b P. thornei DNA amount.

${ }^{\mathrm{c}}$ Efficiency $=$ amplification efficiency, $10^{(1 /-\mathrm{m})}-1$, where $\mathrm{m}$ is the slope of the plot of log pg DNA (x-axis) versus Ct value (y-axis) (10).

TABLE 2. Pratylenchus spp. and GenBank accession numbers of internal transcribed spacer (ITS) sequences used for analysis of primer-template duplex stability $(\Delta \mathrm{G})$ for the real-time polymerase chain reaction primers THO-ITS-F2/THO-ITS-R2

\begin{tabular}{|c|c|c|c|c|c|}
\hline \multirow[b]{2}{*}{ Species } & \multirow[b]{2}{*}{ Accession number } & \multirow[b]{2}{*}{ Isolate $^{\mathrm{a}}$} & \multirow[b]{2}{*}{ Origin } & \multicolumn{2}{|c|}{$\Delta \mathrm{G}(\mathrm{kcal} / \mathrm{mol})^{\mathrm{b}}$} \\
\hline & & & & THO-ITS-F2 & THO-ITS-R2 \\
\hline Pratylenchus thornei & FJ717820 & Clone 1 & United States & -46.1 & -47.4 \\
\hline P. thornei & FJ717821 & Clone 2 & United States & -46.1 & -47.4 \\
\hline P. thornei & FJ713002 & PthKL1 & Spain & -46.1 & -47.4 \\
\hline P. thornei & FJ713003 & PthKL2 & Spain & -46.1 & -47.4 \\
\hline P. thornei & FJ713004 & PthKL3 & Spain & -46.1 & -47.4 \\
\hline P. thornei & FJ713005 & PthKL4 & Spain & -42.6 & -47.4 \\
\hline P. thornei & FJ713006 & PthKL5 & Spain & -39.3 & -47.4 \\
\hline P. agilis & FJ712891 & PagKL5 & United States & - & - \\
\hline P. bolivianus & FJ712896 & PboKL5 & United Kingdom & - & - \\
\hline P. brachyurus & FJ712901 & PbrKL5 & United States & - & - \\
\hline P. coffeae & FJ712906 & PcoKL5 & Vietnam & - & - \\
\hline P. convallariae & FJ712911 & Pc1KL5 & The Netherlands & - & - \\
\hline P. crenatus & FJ712916 & PcrKL5 & Finland & - & - \\
\hline P. fallax & FJ712921 & Pf1KL5 & Belgium & - & - \\
\hline P. goodeyi & FJ712926 & PgoKL5 & Spain & -27.9 & - \\
\hline P. gutierrezi & FJ712931 & Pg1KL5 & Guatemala & - & - \\
\hline P. hippeastri & FJ712936 & PhiKL5 & United States & - & - \\
\hline P. jaehni & FJ712940 & PjaKL4 & Brazil & - & - \\
\hline P. lentis & AM933156 & Clone 23 & Italy & - & - \\
\hline P. loosi & FJ712946 & P11KL5 & Iran & - & - \\
\hline P. mediterraneus & FJ712951 & PmeKL5 & Israel & - & -47.4 \\
\hline P. neglectus & FJ717819 & Clone 1 & United States & - & - \\
\hline P. neglectus & FJ712952 & PneKL1 & Italy & - & - \\
\hline P. neglectus & FJ712956 & PneKL5 & Italy & - & - \\
\hline P. penetrans & FJ712959 & Pp1KL3 & Belgium & _- & - \\
\hline P. penetrans & FJ712978 & Pp14KL2 & Spain & - & - \\
\hline P. penetrans & FJ712991 & Pp18KL5 & United States & - & - \\
\hline P. pinguicaudatus & FJ712996 & PpiKL5 & Tunisia & - & - \\
\hline P. scribneri & FJ713001 & PscKL5 & United States & - & - \\
\hline P. vulnus & FJ713007 & PvuKL1 & France & -20.3 & - \\
\hline P. zeae & FJ713012 & Pz1KL1 & South Africa & - & - \\
\hline
\end{tabular}

${ }^{a}$ Names of isolates were from GenBank or from the paper published by Carta et al. (6).

b Values $<-39 \mathrm{kcal} / \mathrm{mol}$ indicate stable primer-template formation; - = insignificant primer-template duplex stability value. 
infested Walla Walla silt-loam soil. The standard curves generated from DNA diluted with water and soil extract were $y=-3.43 x+$ $35.95\left(R^{2}=1.00\right)$ and $y=-3.45 x+36.00\left(R^{2}=0.98\right)$, respectively. The E for DNA in soil extracts, 0.95 , was very similar to that for DNA in water, 0.96 (Table 3), indicating that the PowerSoil DNA Isolation Kit was able to remove inhibitors from extracts of sterilized and noninfested Walla Walla silt-loam soil. Furthermore, amplification was in the quantitative range $(\mathrm{Ct}<34)(18)$ over seven orders of magnitude of $P$. thorne $i$ DNA (Table 3 ).

Generation of a standard curve from soil. The standard curve generated from the artificially infested soils was described by the equation $y=-3.387 x+29.54\left(R^{2}=0.98\right)$ (Fig. 2A). The E was 0.97 and the $\mathrm{Ct}$ values were 18 to 31 . Amplification curves monitoring the growth of fluorescence versus cycle number for each reaction in the same experiment was shown in Figure 2B. No amplification was observed with control soils that were not inoculated with $P$. thornei. Specific amplification was obtained for the minimum level of inoculation, 0.5 juveniles (mean $\mathrm{Ct}=30.44$ ) or 0.5 adult females (mean $\mathrm{Ct}=30.06$ ) into $0.5 \mathrm{~g}$ of soil, indicating that the real-time PCR assay could detect a single juvenile or a single adult female in $1 \mathrm{~g}$ of soil.

Verification of the standard curve from soil. The validity of the above standard curve was examined using sterilized soil inoculated with known numbers of nematodes. There was a significant correlation (Fig. 3A) $\left(y=0.798 x+3.8, R^{2}=0.84, P<0.001\right.$, $n=20$ ) between the numbers of pure $P$. thornei added to soil (1, $5,20,100$, or 500) and the numbers determined by real-time PCR and the soil standard curve. A high correlation (Fig. 3B) $(y=$ $1.24 x-1.12, R^{2}=0.89, P<0.001, n=22$ ) was also obtained between the numbers of $P$. thornei determined by real-time PCR and the numbers of added $P$. thornei when mixtures of $P$. thornei and $P$. neglectus were used to infest the soil.

Quantification of $P$. thornei from natural field soils. Correlation analysis was conducted to determine the relationship be-

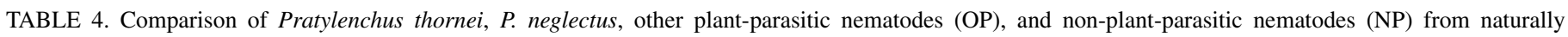
infested field soils determined using the real-time polymerase chain reaction (PCR) assay or microscopic counting method

\begin{tabular}{|c|c|c|c|c|c|c|c|c|c|}
\hline \multirow[b]{4}{*}{ Field soil } & \multirow[b]{4}{*}{ Location } & \multicolumn{8}{|c|}{ Nematodes per kilogram of soil ${ }^{\mathrm{a}}$} \\
\hline & & \multirow{3}{*}{$\frac{\mathrm{PCR}^{\mathrm{b}}}{\text { P. thornei }}$} & \multicolumn{7}{|c|}{ Microscopic counting } \\
\hline & & & \multicolumn{4}{|c|}{ Lab $1^{\mathrm{c}}$} & \multicolumn{3}{|c|}{ P. thornei $i^{\mathrm{d}}$} \\
\hline & & & P. thornei & P. neglectus & $\mathrm{OP}$ & NP & Lab 2 & Lab 3 & Lab 4 \\
\hline FS1 & Lind, WA & $0 \pm 0$ & 0 & 689 & 0 & 2,510 & 87 & 0 & 1,240 \\
\hline FS2 & Lind, WA & $0 \pm 0$ & 0 & 5,385 & 0 & 4,840 & 4,554 & 0 & 1,0366 \\
\hline FS3 & Lind, WA & $0 \pm 0$ & 0 & 53 & 0 & 5,220 & 0 & 0 & 54 \\
\hline FS4 & Ralston, WA & $0 \pm 0$ & 0 & 0 & 0 & 6,150 & 0 & 0 & 0 \\
\hline FS5 & Imbler, OR & $88 \pm 58$ & 0 & 4,016 & 766 & 7,154 & 0 & 0 & 0 \\
\hline FS6 & Union, OR & $0 \pm 0$ & 0 & 2,175 & 1,982 & 7,180 & 0 & 0 & 0 \\
\hline FS7 & Island City, OR & $0 \pm 0$ & 0 & 1,733 & 1,320 & 8,852 & 1,938 & 0 & 0 \\
\hline FS8 & Mission, OR & $184 \pm 66^{* *}$ & $1,361 * *$ & 5,964 & 816 & 10,192 & 5,247 & 60 & 7,162 \\
\hline FS9 & Imbler, OR & $0 \pm 0$ & 0 & 2,182 & 351 & 7,500 & 1,436 & 0 & 0 \\
\hline FS10 & Moro, OR & $0 \pm 0$ & 0 & 553 & 14 & 3,838 & 0 & 0 & 1,254 \\
\hline FS11 & Pendleton, OR & $3,672 \pm 1,136$ & 812 & 974 & 14 & 2,742 & 898 & 120 & 2,846 \\
\hline FS12 & Pendleton, OR & $0 \pm 0$ & 0 & 463 & 56 & 5,628 & 276 & 30 & 3,182 \\
\hline FS13 & Pendleton, OR & $7,774 \pm 1,705$ & 1,871 & 3,700 & 76 & 4,224 & 5,176 & 40 & 484 \\
\hline FS14 & Pendleton, OR & $90 \pm 27$ & 0 & 2,156 & 52 & 5,820 & 1,692 & 0 & 0 \\
\hline FS15 & Pendleton, OR & $6,515 \pm 1,259$ & 2,691 & 629 & 1,046 & 6,060 & 0 & 110 & 692 \\
\hline
\end{tabular}

${ }^{a}$ Real-time PCR estimate followed by asterisks (**) for the sample FS8 is significantly different $(P<0.01)$ than the microscopic count from lab 1.

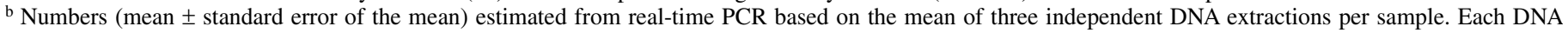
extract was analyzed in duplicate.

${ }^{c}$ Numbers reported using the Whitehead tray and microscope-based identification and counting.

${ }^{\mathrm{d}}$ Numbers reported using the wet-sieving and sugar-density flotation methods.

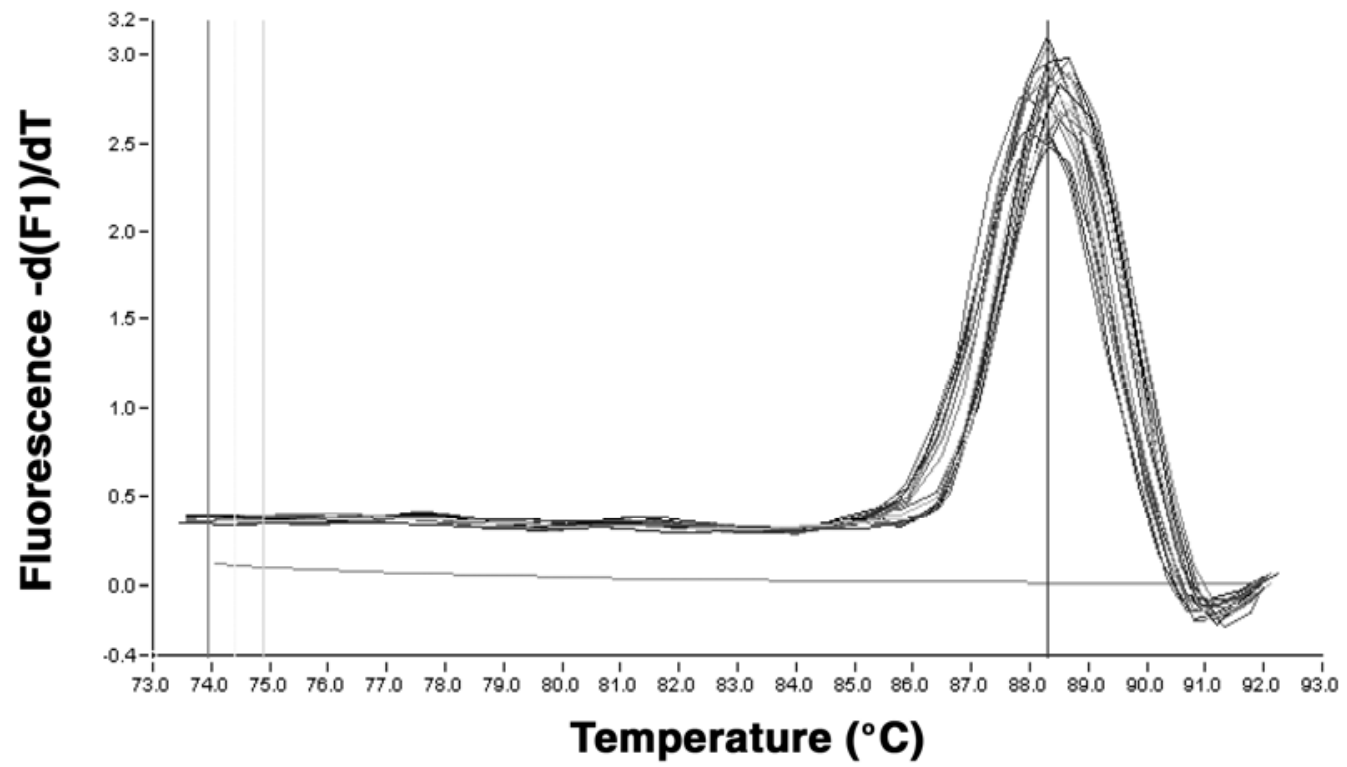

Fig. 1. Melting curve profiles of Pratylenchus thornei-specific amplicons with melting temperature at $88.4^{\circ} \mathrm{C}$. 
tween nematode numbers detected by the real-time PCR assay and the numbers reported from four labs using microscopic methods for the 15 soil samples collected from Oregon and Washington infested wheat fields (Table 5). There was a strong $\left(R^{2}=\right.$ $0.762)$ and significant $(P<0.001)$ positive correlation between the numbers based on the real-time PCR and reported by lab 1 that used the Whitehead tray extraction and microscopic counting method. The equation $(y=2.65 x+33)$ also showed that counts determined by the real-time PCR generally can be expected to overestimate the numbers of nematodes derived from the Whitehead tray and microscopic method but this overestimation was not significantly different $(P=0.136$, paired $t$ test $)$. Out of the 15 soil samples, only 1 sample (FS8) showed significant difference $(P<$ $0.01)$ between the estimates from the real-time PCR and the Whitehead tray methods (Table 4), indicating that the numbers detected by the real-time PCR can reflect the nematode levels in $93 \%$ of the soil samples. The numbers of $P$. thornei determined by the real-time PCR assay and labs 1 to 4 , as well as $P$. neglectus, other plant-parasitic nematodes, and non-plant-parasitic nematodes determined by lab 1 for these 15 field soil samples, are shown in Table 4 . There were poor correlations $\left(R^{2}<0.5\right)$ between the numbers based on the real-time PCR and the numbers reported by labs 2 to 4 that used wet-sieving and sugar-flotation extraction methods (Table 5).

Quantification of $P$. thornei from greenhouse soils. Resistance reactions ( $\mathrm{R}, \mathrm{S}$, and I) for 20 wheat lines were determined based on the real-time PCR assay and the Whitehead tray-microscopic method (Table 6). Both methods resulted in identical reactions for 17 of the 20 lines. Three lines differed in reaction type (GS7, R versus I; GS16, I versus R; and GS17, S versus I), indicating that real-time PCR predicted the phenotypes in $85 \%$ of the tested lines, and that there were no instances for which the two procedures provided contradictory assignments of susceptible versus resistant phenotypes.

Correlation analysis was conducted to determine the relationship between nematode numbers determined by the real-time

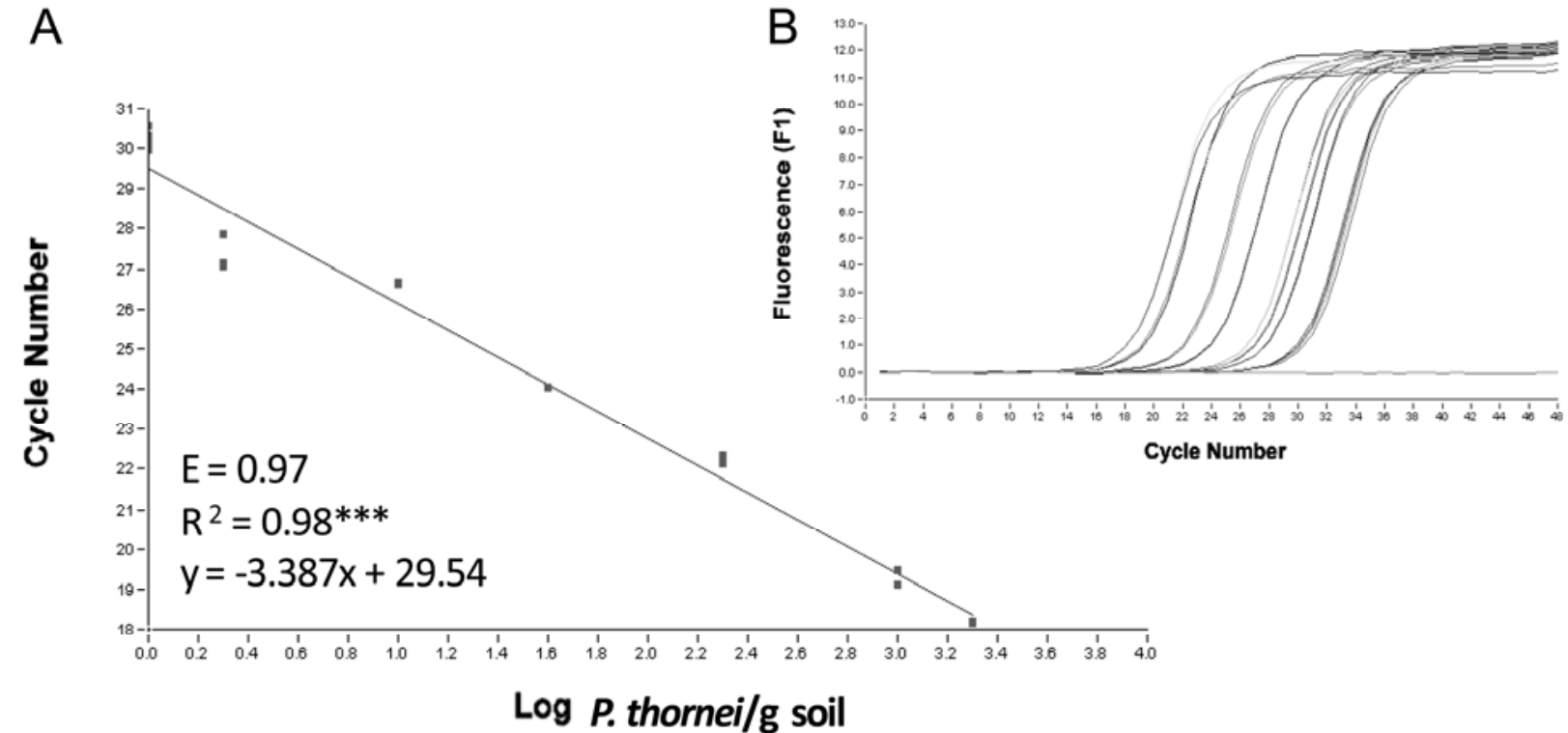

Fig. 2. Real-time polymerase chain reaction assay for Pratylenchus thornei. A, Standard curve of threshold cycle number plotted against the log of the number of $P$. thornei $(0.5,1,5,20,100,500$, and 1,000$)$ inoculated into $0.5 \mathrm{~g}$ of sterilized soil. Amplification efficiency $(\mathrm{E})=10^{1 / \text { slope }}-1 ; * * *$ indicates significant at $P<$ 0.001. B, Amplification curves of each reaction for the same experiment. Control reactions without $P$. thornei DNA template did not produce any amplification.

A

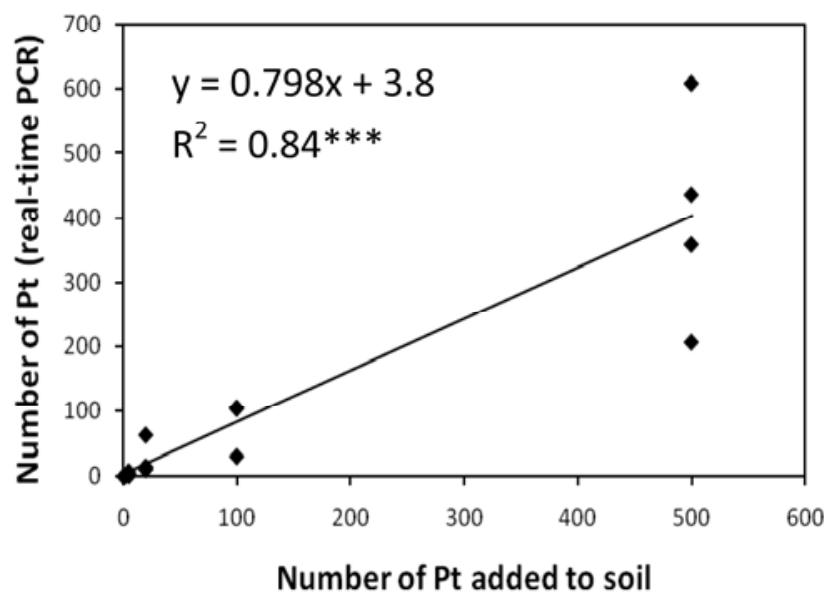

B

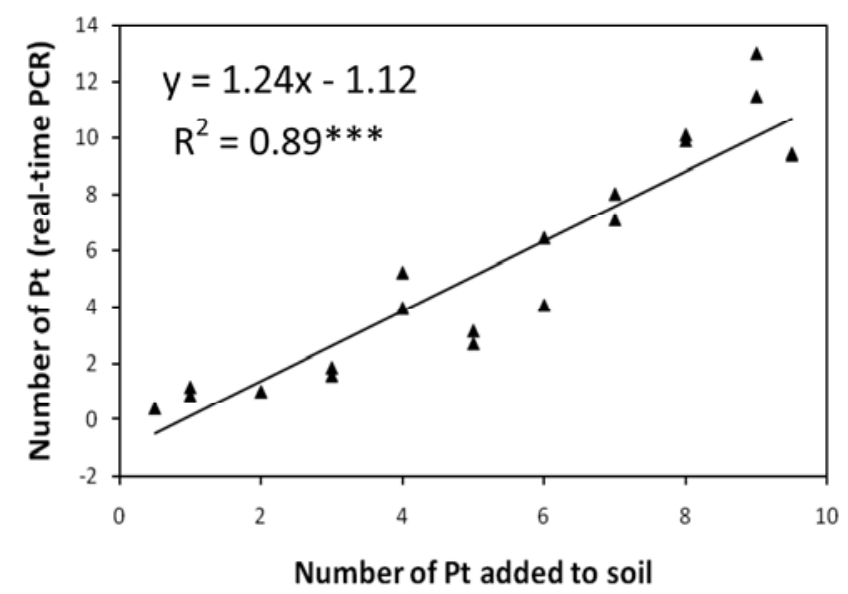

Fig. 3. Correlation between the number of Pratylenchus thornei $(\mathrm{Pt})$ determined by real-time polymerase chain reaction and the number of $P$. thornei added to soil. A, Pure P. thornei $(1,5,20,100$, and 500) were added separately to $0.5 \mathrm{~g}$ of sterilized soil. B, Mixtures of P. thornei and P. neglectus $(\mathrm{Pn})(0.5 \mathrm{Pt}+9.5 \mathrm{Pn}, 1 \mathrm{Pt}+9 \mathrm{Pn}$, $2 \mathrm{Pt}+8 \mathrm{Pn}, 3 \mathrm{Pt}+7 \mathrm{Pn}, 4 \mathrm{Pt}+6 \mathrm{Pn}, 5 \mathrm{Pt}+5 \mathrm{Pn}, 6 \mathrm{Pt}+4 \mathrm{Pn}, 7 \mathrm{Pt}+3 \mathrm{Pn}, 8 \mathrm{Pt}+2 \mathrm{Pn}, 9 \mathrm{Pt}+1 \mathrm{Pn}$, and $9.5 \mathrm{Pt}+0.5 \mathrm{Pn}$ ) were added to $0.5 \mathrm{~g}$ of sterilized soil; *** indicates significant at $P<0.001$. 
PCR assay and by the Whitehead tray extraction and microscopic counting method for the 20 wheat lines (Fig. 4). There was a significant positive correlation $\left(R^{2}=0.65, P<0.001\right)$ between the estimates of the numbers of $P$. thornei determined by the real-time PCR assay and by the Whitehead method. The equation $(y=$ $0.858 x$ - 248) showed that counts based on the real-time PCR generally can be expected to underestimate the numbers of nematodes derived from microscopic method but this underestimation was not significantly different $(P=0.236$, paired $t$ test $)$.

\section{DISCUSSION}

The plant-parasitic root-lesion nematode $P$. thornei was detected and quantified in a variety of soil samples using extracts of soil DNA and SYBR Green I-based real-time PCR, a relatively inexpensive chemistry. The assumption of measuring the nematode number by real-time PCR is that the number of target DNA copies in the sample is proportional to the number of target nematodes (16). Our real-time PCR assay was sensitive, reliably detecting a single juvenile of genomic DNA in $1 \mathrm{~g}$ of sterilized and infested soil. The assay had high amplification efficiency and also was highly specific, showing a single amplicon in melting curve analyses and no specific amplification using DNA from a variety of non-target nematodes and fungal species that are found in PNW dryland wheat fields. To our knowledge, this is the first

TABLE 5. Correlation between the numbers of Pratylenchus thornei detected using real-time polymerase chain reaction (PCR) and the numbers reported by four commercial or research labs for the 15 field soil samples ${ }^{\mathrm{a}}$

\begin{tabular}{lccl}
\hline Lab number $^{\mathrm{b}}$ & $R^{2}$ & $P$ & \multicolumn{1}{c}{ Equation } \\
\hline 1 & 0.762 & 0.000 & $y=2.65 x+33$ \\
2 & 0.068 & 0.348 & $y=0.343 x+735$ \\
3 & 0.480 & 0.004 & $y=43.4 x+180$ \\
4 & 0.014 & 0.671 & $y=-0.101 x+1,406$ \\
\hline
\end{tabular}

${ }^{a}$ The 15 field soil samples are described in Table 4; $y=$ real-time PCR estimation and $x=$ traditional nematode extraction and microscopic estimation.

${ }^{\mathrm{b}}$ Real-time PCR counts versus each lab. open-source report describing real-time PCR protocols, including primers, soil extraction, and standard curves, to detect and quantify $P$. thornei from field and greenhouse soils.

The $P$. thorne $i$-specific primer set (PTHO/D3B) from the D3 expansion domain of the 28S rRNA used by Al-Banna et al. (1) and Yan et al. (41) in conventional PCR was tested but this primer pair was not sufficiently specific, and consistently produced a minor secondary amplicon in melt curve analyses (data not shown), leading to false overestimation of the target DNA. We tested several other primer sets from the D3 expansion domain but they were also not specific. This is likely due to the greater sensitivity of the real-time PCR assay compared with conventional PCR-gel electrophoresis. Carrasco-Ballesteros et al. (5) identified $P$. thornei using conventional PCR and SCAR primers. However, the SCAR primers produced a DNA fragment which is much longer in size $(1,078 \mathrm{bp})$ than the maximum of $400 \mathrm{bp}$ required for efficient amplicon melting in our real-time PCR system. Therefore, we designed new real-time PCR primers, THO-ITS-F2 and

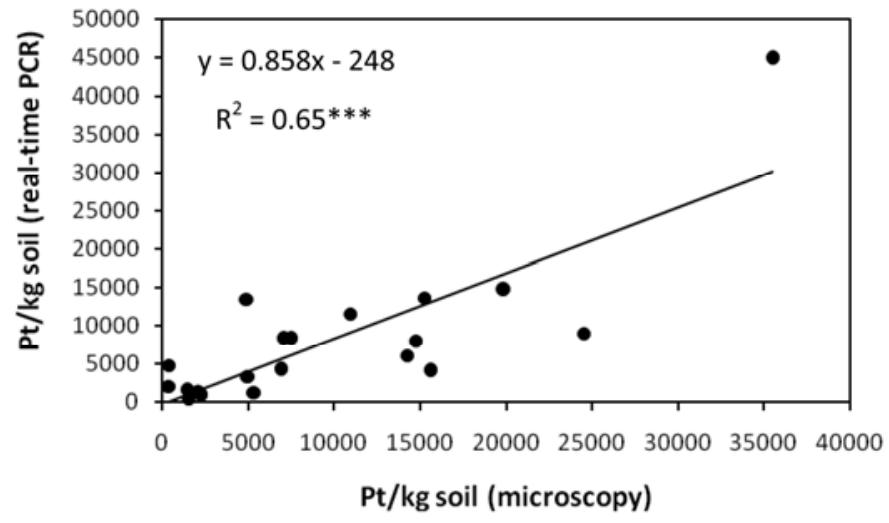

Fig. 4. Correlation between the numbers of Pratylenchus thornei $(\mathrm{Pt})$ determined by the real-time polymerase chain reaction assay and by the Whitehead tray extraction and microscopic counting method from soil of a wheat resistance trial in the greenhouse; $* * *$ indicates significant at $P<0.001$.

TABLE 6. Quantification of Pratylenchus thornei in greenhouse soil using real-time polymerase chain reaction (PCR) and a microscopic method, and evaluation of resistance reactions for 20 wheat lines grown in this soil

\begin{tabular}{|c|c|c|c|c|c|c|}
\hline \multirow[b]{2}{*}{ Wheat line } & \multicolumn{3}{|c|}{ Microscopic estimation } & \multicolumn{3}{|c|}{ Real-time PCR estimation } \\
\hline & P. thorne $i^{\mathrm{a}}$ & $\mathrm{MR}^{\mathrm{b}}$ & Reaction $^{\mathrm{c}}$ & P. thornei $i^{\mathrm{d}}$ & $\mathrm{MR}^{\mathrm{b}}$ & Reaction $^{\mathrm{c}}$ \\
\hline GS1 & 35,510 & 17.8 & $\mathrm{~S}$ & $45,017 \pm 2,450$ & 22.5 & $\mathrm{~S}$ \\
\hline GS4 & 343 & 0.2 & $\mathrm{R}$ & $2,007 \pm 48$ & 1.0 & $\mathrm{R}$ \\
\hline GS5 & 4,865 & 2.4 & I & $13,514 \pm 2,215$ & 6.8 & I \\
\hline GS6 & 6,897 & 3.4 & I & $4,342 \pm 892$ & 2.2 & I \\
\hline GS9 & 15,275 & 7.6 & I & $13,653 \pm 232$ & 6.8 & I \\
\hline GS10 & 1,533 & 0.8 & $\mathrm{R}$ & $423 \pm 27$ & 0.2 & $\mathrm{R}$ \\
\hline GS11 & 14,245 & 7.1 & I & $6,100 \pm 166$ & 3.1 & I \\
\hline GS12 & 7,510 & 3.8 & I & $8,368 \pm 484$ & 4.2 & I \\
\hline GS13 & 2,232 & 1.1 & $\mathrm{R}$ & $986 \pm 321$ & 0.5 & $\mathrm{R}$ \\
\hline GS14 & 4,934 & 2.5 & I & $3,297 \pm 258$ & 1.6 & I \\
\hline GS15 & 10,935 & 5.5 & I & $11,558 \pm 1,894$ & 5.8 & I \\
\hline
\end{tabular}

a Numbers of $P$. thornei were obtained using the Whitehead tray and microscopic identification and counting procedures and were expressed as $P$. thornei/kg of soil.

${ }^{\mathrm{b}}$ Multiplication rate (MR) was calculated by dividing the final number of nematodes extracted from soil plus roots after 16 weeks of plant growth by the number of nematodes initially inoculated into the soil. The initial inoculation rate was 2,000 P. thornei $/ \mathrm{kg}$ of soil.

${ }^{\mathrm{c}}$ Reaction indicated the resistance evaluation of the wheat lines grown in this soil. Resistance (R): MR $\leq 1$; intermediate (I): $1<$ MR $<10$; and susceptible (S): $\mathrm{MR} \geq 10$.

${ }^{\mathrm{d}}$ Numbers of $P$. thornei (mean \pm standard error of the mean) were estimated from real-time PCR based on the mean of two independent DNA extractions for each sample and were expressed as $P$. thornei $/ \mathrm{kg}$ of soil. Each DNA extract was analyzed in duplicate. 
THO-ITS-R2, from the ITS1 of the ribosomal RNA genes. Our findings illustrated the specificity of the primers in the soil community of dryland wheat fields in eastern Oregon and Washington. Pratylenchus is a diverse genus containing nearly 70 species (7). Further testing of these primers with other Pratylenchus spp. and local species in soil may be necessary if these primers were used for diagnosis with DNA extracts from soil in other areas.

The real-time PCR assay detected at least 0.5 juvenile in $0.5 \mathrm{~g}$ of soil, equating to 1,000 juveniles $/ \mathrm{kg}$ of soil. Lower numbers of nematodes were not examined and, therefore, 0.5 of a $P$. thornei body may not represent the lowest detection sensitivity of this assay. However, this sensitivity compares well with findings reported by other researchers. Ciancio et al. (8) were able to detect a single juvenile of the root-knot nematode Meloidogyne incognita. Madani et al. (16) could detect a single second-stage juvenile of cyst-forming nematodes Globodera pallida and Heterodera schachtii. Sato et al. (24) could detect a single second-stage juvenile of $P$. penetrans in the presence of 800 free-living nematodes. Toyota et al. (36) reported that real-time PCR sensitively detected a single second-stage juvenile of G. rostochiensis from 1,000 free-living nematodes. More importantly, the detection sensitivity obtained in this study was much lower than the presumptive economic threshold level (2,000 nematodes $/ \mathrm{kg}$ of soil) in the Pacific Northwest (31), suggesting that the assay will be useful for assessing disease risk and providing management strategies.

The real-time PCR assay was accurate in estimating the numbers of $P$. thornei in artificially infested soil samples, as shown from the standard curve, where the $\mathrm{Ct}$ values were significantly inversely correlated with the log values of nematode numbers. The standard curve was generated from a range of nematode individuals added to soils and not from serial dilutions of one concentrated sample with a high number of nematodes. Higher variations were found in DNA samples obtained from different numbers of nematode individuals than in simply diluted DNA samples in identifying $P$. penetrans in a nematode community using real-time PCR (24). The standard curve appears to be representative of the type of variation that may occur among samples with the same number of nematodes and, thereby, tends to be more representative of the variation that may exist in natural field samples (3).

There was a good and significant positive correlation between the numbers detected by real-time PCR and reported by lab 1 using the Whitehead tray extraction method. However, there were poor correlations with numbers reported by labs 2 to 4 using the wet-sieving and sugar-density flotation methods. The differences among laboratories may be due to degree of variation in accuracy of nematode extraction, sampling from nematode suspensions, and nematode counting, and may also reflect the difficulty in Pratylenchus sp. identification using traditional microscopic methods. Laboratories estimated the number of each species of $P$. thornei and $P$. neglectus based on the proportion of adult females with visual diagnostic features rather than the total number of juveniles, eggs, and adults that are present in a sample. Poor correlations found between labs 2 to 4 for the same soil samples $\left(R^{2}=0.01\right.$ for lab 2 and lab $3 ; R^{2}=0.38$ for lab 2 and lab $4 ; R^{2}=0.03$ for lab 3 and lab 4) also indicated that it was challenging to distinguish $P$. thornei and P. neglectus, probably due to the minor morphological difference and the variability of individual specimens within a population.

When tested on natural field and greenhouse soil samples, the real-time PCR data correlated well with counts based on the Whitehead tray extraction and microscopic method. Although, in general, the real-time PCR tended to overestimate the numbers of nematodes in the field samples and underestimate the numbers of nematodes in the greenhouse samples, there was no significant difference between it and the Whitehead method. Some researchers have noted under- or overestimation of nematode numbers using real-time PCR. Ophel-Keller et al. (19) reported that a DNA assay tended to overestimate population densities of $P$. thornei (nematodes per kilogram of soil) compared with a manual method from cereal-growing soils in Queensland, Australia. Toyota et al. (36) also reported overestimation of nematode numbers based on real-time PCR compared with morphological identification in estimating the number of $G$. rostochiensis juveniles. Berry et al. (3) found that real-time PCR tended to underestimate the numbers of nematodes ( $M$. javanica, P. zeae, and Xiphinema elongatum) in most cases. Goto et al. (11) found that overestimation of the number of soybean cysts $(H$. glycines) with realtime PCR methods compared with a sieving method.

The discrepancy in nematode numbers determined using realtime PCR and microscope-based counting may be due to the uneven distribution of nematodes in soil $(20,40,41)$. A small amount of soil $(\leq 0.5 \mathrm{~g})$ was recommended for DNA extraction using the PowerSoil DNA Isolation Kit whereas $\approx 200 \mathrm{~g}$ of soil was processed using the Whitehead tray and microscopic method. Thorough mixing of soil samples and use of more DNA extraction replicates for each sample could reduce possible error. Another factor might be the inhibition of PCR amplification. Some researchers have reported that different degrees of inhibition within environmental samples might cause potential under- or overestimation $(8,15)$. In the present study, soil extracts of sterilized, noninfested Walla Walla silt loam (used for generation of the standard curve from soil) yielded an amplification efficiency similar to that for water controls, and the DNA extraction method applied to 15 field soil samples and 20 greenhouse soil samples. However, inhibition was found in these soil samples in comparison with the water control as well as the control of sterilized, noninfested soil extracts using pUC 19 plasmid and plasmidspecific primers M13F and M13R. In all, $3 \times 10^{5}$ copies of pUC 19 plasmid were added to real-time PCR reactions and detected by the real-time PCR. The $\mathrm{Ct}(30.9 \pm 0.2)$ of the soil extract control was similar to the $\mathrm{Ct}(31.4 \pm 0.1)$ of the water control. No plasmid-specific amplicon was observed from the greenhouse and field soil samples, indicating that these soil samples had inhibitory effects on the real-time PCR. Removal of the PCR inhibitors by adding insoluble polyvinylpolypyrrolidone to the soil extracts, adding bovine serum albumin to the real-time PCR reaction mixtures, diluting the soil extracts, or the combination of these methods $(18,41)$ might help reduce the discrepancy between the numbers based on real-time PCR and the Whitehead and microscopic method. Although the variation existed between the two methods, the significant correlation $\left(R^{2}=0.762\right)$ obtained in this study between the two methods was comparable with the correlation $\left(R^{2}=0.7446\right)$ between counts of $P$. thornei from a microscopic method and a proprietary DNA assay reported from Ophel-Keller et al. (19) in Australia.

A particular strength of real-time PCR is that it is useful for quantifying mixed populations of Pratylenchus spp. (e.g., $P$. thornei in the presence of $P$. neglectus), where visual identification of juvenile and egg stages into species is extremely difficult. In commercial labs, Pratylenchus spp. are routinely quantified to the genus level, which is not adequate for serving wheatbased agricultural systems in which Pratylenchus sp.-specific tolerant and resistant cultivars are being developed (27). For $P$. neglectus, the conventional PCR primer pair described by Yan et al. (41) was tested in a parallel study using real-time PCR. This primer pair showed a high specificity but its detection sensitivity was low and its amplification efficiency was variable among different experiments (data not shown). New species-specific realtime PCR primers are being developed and tested for the accuracy of detection and quantification of $P$. neglectus from soil.

Our study has shown that the real-time PCR assay using SYBR Green I dye can be used to detect and quantify $P$. thornei from artificially infested soils, greenhouse soils, and naturally infested field soils. Unlike most other publications using individual nematodes from nematode suspension or in nematode communities $(3,16,24,36)$, our real-time PCR was performed on total DNA 
directly extracted from soil, which eliminated the need for timeconsuming manual nematode extraction, microscopic identification, and counting steps. This assay forms the basis of a useful tool for rapid and efficient detection and quantification of $P$. thornei from a large number of field soil samples and from a large scale of cereal resistance screening trials in greenhouse.

\section{ACKNOWLEDGMENTS}

This research was supported by the Oregon State University, Agricultural Research Foundation project ARF 7135A, and a subcontract between Oregon State University and the United States Department of Agriculture-Agricultural Research Service (USDA-ARS) (SCA 58-5348-9-100, "Control of Root Diseases of Wheat and Barley"), and USDA-ARS project number 5248-22000-012-00D (P. A. Okubara). We thank S. H. Hulbert and C. Yin at Washington State University for use of the NanoDrop ND-1000 Spectrophotometer; A. Dyer, S. Hafez, A. Skantar, E. Riga, and M. Mazzola for providing isolates of control nematode and fungal species; and C. L. Reardon for providing pUC 19 plasmid and M13F and M13R primers.

\section{LITERATURE CITED}

1. Al-Banna, L., Ploeg, A. T., Williamson, V. M., and Kaloshian, I. 2004. Discrimination of six Pratylenchus species using PCR and speciesspecific primers. J. Nematol. 36:142-146.

2. Atallah, Z. K., Bae, J., Jansky, S. H., Rouse, D. I., and Stevenson, W. R. 2007. Multiplex real-time quantitative PCR to detect and quantify Verticillium dahliae colonization in potato lines that differ in response to Verticillium wilt. Phytopathology 97:865-872.

3. Berry, S. D., Fargette, M., Spaull, V. W., Morand, S., and Cadet, P. 2008. Detection and quantification of root-knot nematode (Meloidogyne javanica), lesion nematode (Pratylenchus zeae) and dagger nematode (Xiphinema elongatum) parasites of sugarcane using real-time PCR. Mol. Cell Probes 22:168-176.

4. Burlakoti, R. R., Estrada, R., Jr., Rivera, V. V., Boddeda, A., Secor, G. A., and Adhikari, T. B. 2007. Real-time PCR quantification and mycotoxin production of Fusarium graminearum in wheat inoculated with isolates collected from potato, sugar beet, and wheat. Phytopathology 97:835-841.

5. Carrasco-Ballesteros, S., Castillo, P., Adams, B. J., and Pérez-Artés, E. 2007. Identification of Pratylenchus thornei, the cereal and legume rootlesion nematode, based on SCAR-PCR and satellite DNA. Eur. J. Plant Pathol. 118:115-125.

6. Carta, L. K., Skantar, A. M., and Handoo, Z. A. 2001. Molecular, morphological and thermal characters of 19 Pratylenchus spp. and relatives using the D3 segment of the nuclear LSU rRNA gene. Nematropica 31:193-207.

7. Castillo, P., and Vovlas, N. 2007. Pratylenchus, Nematoda, Pratylenchidae: Diagnosis, biology, pathogenicity and management. Nematol. Monogr. Perspect. 6:1-530.

8. Ciancio, A., Loffredo, A., Paradies, F., Turturo, C., and Finetti-Sialer, M. 2005. Detection of Meloidogyne incognita and Pochonia chlamydosporia by fluorogenic molecular probes. EPPO Bull. 35:157-164.

9. Filho, A. C. C., and Huang, C. S. 1989. Description of Pratylenchus pseudofallax $\mathrm{n}$. sp. with a key to species of the genus Pratylenchus Filipjev, 1936 (Nematoda: Pratylenchidae). Rev. Nematol. 12:7-15.

10. Ginzinger, D. G. 2002. Gene amplification using real-time quantitative PCR: An emerging technology hits the mainstream. Exp. Hematol. 30:503-512.

11. Goto, K., Sato, E., and Toyota, K. 2009. A novel detection method for the soybean cyst nematode Heterodera glycines using soil compaction and real-time PCR. Jpn. J. Nematol. 39:1-7.

12. Handoo, Z. A., and Golden, A. M. 1989. A key and diagnostic compendium to the species of the genus Pratylenchus Filpjev, 1936 (lesion nematodes). J. Nematol. 21:202-218.

13. Hollaway, G. J., Ophel-Keller, K. M., Taylor, S. P., Burns, R. A., and McKay, A. C. 2003. Effect of soil water content, sampling method and sample storage on the quantification of root-lesion nematodes (Pratylenchus spp.) by different methods. Australas. Plant Pathol. 32:73-79.

14. Jenkins, W. R. 1964. A rapid centrifugal-flotation technique for separating nematodes from soil. Plant Dis. Rep. 48:692.

15. Leal, I., Green, M., Allen, E., Humble, L., and Rott, M. 2007. Application of a real-time PCR method for the detection of pine wood nematode, Bursaphelenchus xylophilus, in wood samples from lodgepole pine. Nematology 9:351-362.

16. Madani, M., Subbotin, S. A., and Moens, M. 2005. Quantitative detection of the potato cyst nematode, Globodera pallida and the beet cyst nematode, Heterodera schachtii, using real-time PCR with SYBR green I dye. Mol. Cell. Probe. 19:81-86.

17. Nakhla, M. K., Owens, K. J., Li, W., Wei, G., Skantar, A. M., and Levy, L. 2010. Multiplex real-time PCR assays for the identification of the potato cyst and tobacco cyst nematodes. Plant Dis. 94:959-965.

18. Okubara, P. A., Schroeder, K. L., and Paulitz, T. C. 2008. Identification and quantification of Rhizoctonia solani and $R$. oryzae using real-time polymerase chain reaction. Phytopathology 98:837-847.

19. Ophel-Keller, K., McKay, A., Hartley, D., Herdina, and Curran, J. 2008. Development of a routine DNA-based testing service for soilborne diseases in Australia. Australas. Plant Pathol. 37:243-253.

20. Qiu, J. J., Westerdahl, B. B., Anderson, C., and Williamson, V. 2006. Sensitive PCR detection of Meloidogyne arenaria, M. incognita, and $M$. javanica extracted from soil. J. Nematol. 38:434-441.

21. Qiu, J., Westerdahl, B. B., and Williamson, V. M. 2007. Detection and quantification of root-lesion nematode Pratylenchus vulnus using realtime PCR. (Abstr.) J. Nematol. 39:95.

22. Riley, I. T., Nobbs, J. M., Herdina, and McKay, A. C. 2009. Pratylenchus species in pastures in the south east region of South Australia. Australas. Plant Dis. Notes 4:89-90.

23. Rychlik, W., and Rhoads, R. E. 1989. A computer program for choosing optimal oligonucleotides for filter hybridization, sequencing and in vitro amplification of DNA. Nucleic Acids Res. 17:8543-8552.

24. Sato, E., Min, Y. Y., Shirakashi, T., Wada, S., and Toyota, K. 2007. Detection of the root-lesion nematode, Pratylenchus penetrans (Cobb), in a nematode community using real-time PCR. Jpn. J. Nematol. 37:87-92.

25. Schroeder, K. L., Okubara, P. A., Tambong, J. T., Lévesque, C. A., and Paulitz, T. C. 2006. Identification and quantification of pathogenic Pythium spp. from soils in eastern Washington using real-time polymerase chain reaction. Phytopathology 96:637-647.

26. Smiley, R. W. 2009. Root-lesion nematodes reduce yield of intolerant wheat and barley. Agron. J. 101:1322-1335.

27. Smiley, R. W. 2010. Root-lesion nematodes: Biology and management in Pacific Northwest wheat cropping systems. PNW Ext. Bull. 617, Oreg. State Univ. Corvallis.

28. Smiley, R. W., and Machado, S. 2009. Pratylenchus neglectus reduces yield of winter wheat in dryland cropping systems. Plant Dis. 93:263-271.

29. Smiley, R. W., Merrifield, K., Patterson, L.-M., Whittaker, R. G., Gourlie, J. A., and Easley, S. A. 2004. Nematodes in dryland field crops in the semiarid Pacific Northwest United States. J. Nematol. 36:54-68.

30. Smiley, R. W., and Nicol, J. M. 2009. Nematodes which challenge global wheat production. Pages 171-187 in: Wheat: Science and Trade. B. F. Carver, ed. Wiley-Blackwell, Ames, IA.

31. Smiley, R. W., Whittaker, R. G., Gourlie, J. A., and Easley, S. A. 2005. Pratylenchus thornei associated with reduced wheat yield in Oregon. J. Nematol. 37:45-54.

32. Smiley, R. W., Whittaker, R. G., Gourlie, J. A., and Easley S. A. 2005. Suppression of wheat growth and yield by Pratylenchus neglectus in the Pacific Northwest. Plant Dis. 89:958-968.

33. Strausbaugh, C. A., Bradley, C. A., Koehn, A. C., and Forster, R. L. 2004. Survey of root diseases of wheat and barley in southeastern Idaho. Can. J. Plant Pathol. 26:167-176.

34. Subbotin, S. A., Ragsdale, E. J., Mullens, T., Roberts, P., and Baldwin, J. G. 2007. Molecular diagnostics and phylogenetic relationships of some species of root-lesion nematodes of the genus Pratylenchus. (Abstr.) J. Nematol. 39:80.

35. Thompson, J. P., Owen, K. J., Stirling, G. R., and Bell, M. J. 2008. Rootlesion nematodes (Pratylenchus thornei and P. neglectus): A review of recent progress in managing a significant pest of grain crops in northern Australia. Australas. Plant Pathol. 37:235-242.

36. Toyota, K., Shirakashi, T., Sato, E., and Wada, S. 2008. Development of a real-time PCR method for the potato-cyst nematode Globodera rostochiensis and the root-knot nematode Meloidogyne incognita. Soil Sci. Plant Nutr. 54:72-76.

37. Vanstone, V. A., Hollaway, G. J., and Stirling, G. R. 2008. Managing nematode pests in the southern and western regions of the Australian cereal industry: Continuing progress in a challenging environment. Australas. Plant Pathol. 37:220-234.

38. Waeyenberge, L., Ryss, A., Moens, M., Pinochet, J., and Vrain, T. C. 2000. Molecular characterization of 18 Pratylenchus species using rDNA restriction fragment length polymorphism. Nematology 2:135-142.

39. Whitehead, A. G., and Hemming, J. R. 1965. A comparison of some quantitative methods of extracting small vermiform nematodes from soil. Ann. Appl. Biol. 55:25-38.

40. Yan, G. P., and Smiley, R. W. 2010. Distinguishing Heterodera filipjevi and $H$. avenae using polymerase chain reaction-restriction fragment length polymorphism and cyst morphology. Phytopathology 100:216-224.

41. Yan, G. P., Smiley, R. W., Okubara, P. A., Skantar, A., Easley, S. A., Sheedy, J. G., and Thompson, A. L. 2008. Detection and discrimination of Pratylenchus neglectus and $P$. thornei in DNA extracts from soil. Plant Dis. 92:1480-1487. 